\title{
Methodology of the tetrazolium test for assessing the viability of seeds of Eugenia brasiliensis Lam., Eugenia uniflora L. and Eugenia pyriformis Cambess ${ }^{1}$
}

\begin{abstract}
Edmir Vicente Lamarca²*, Claudio José Barbedo²
ABSTRACT - Eugenia brasiliensis Lam. (“grumixameira"), Eugenia uniflora L. (“pitangueira”) and Eugenia pyriformis Cambess. ("uvaieira") are forest and fruit species of pharmacological and gastronomic potential and have desiccation-sensitive seeds. The development of quick viability tests for the assessment of physiological quality of these seeds is needed. The tetrazolium test is an important method providing fast assessment of the seed physiological quality. Thus, this work aimed to develop a method for the tetrazolium test for determining viability of "grumixameira," "pitangueira" and "uvaieira" seeds. Initially the seeds of these species were soaked in water for $3 \mathrm{~h}$ at $25^{\circ} \mathrm{C}$. Three concentrations of tetrazolium solutions were analyzed $(0.100 \%, 0.125 \%$ and $0.250 \%)$ for seed staining using three incubation periods $(2,3$ and $6 \mathrm{~h})$ at $35{ }^{\circ} \mathrm{C}$ in the dark. After staining, seed viability was determined. Then, the seeds were subjected to different levels of controlled drying and were analyzed for their physiological quality by germination and electrical conductivity tests. The tetrazolium test is a suitable tool for determining viability after staining the seeds at $35{ }^{\circ} \mathrm{C}$ using a $0.250 \%$ concentration solution for 3 hours for "grumixameira" seeds, $0.125 \%$ for 3 hours for "pitangueira" seeds and $0.100 \%$ for 2 hours for "uvaieira" seeds.
\end{abstract}

Index terms: forest seeds, recalcitrant seeds, drying, viability test.

\section{Metodologia do teste de tetrazólio para a avaliação da viabilidade de sementes de Eugenia brasiliensis Lam., Eugenia uniflora L. e Eugenia pyriformis Cambess}

\begin{abstract}
RESUMO - Grumixameira (Eugenia brasiliensis Lam.), pitangueira (Eugenia uniflora L.) e uvaieira (Eugenia pyriformis Cambess.) são espécies florestais e frutíferas de potencial farmacológico e gastronômico e apresentam sementes sensíveis à dessecação. O teste de tetrazólio é um importante componente para a rápida avaliação da viabilidade de sementes. Assim, o presente estudo teve como objetivo adequar a metodologia do teste de tetrazólio para a determinação da viabilidade de sementes de grumixameira, pitangueira e uvaieira. Sementes dessas três espécies foram pré-umedecidas em água por $3 \mathrm{~h}$ a $25^{\circ} \mathrm{C}$. Após, foram coloridas com soluções de tetrazólio nas concentrações de $0,100 \%, 0,125 \%$ e $0,250 \%$ por 2,3 e 6 horas, a $35{ }^{\circ} \mathrm{C}$ no escuro. Após lavagem, determinou-se a viabilidade das sementes. As sementes foram também submetidas a diferentes níveis de secagem e foram analisadas quanto aos seus atributos fisiológicos pelos testes de germinação e condutividade elétrica. $\mathrm{O}$ teste de tetrazólio, com coloração das sementes a $35{ }^{\circ} \mathrm{C}$ usando-se uma concentração da solução de $0,250 \%$ com incubação por 3 horas para sementes de grumixameira, a $0,125 \%$ por 3 horas para sementes de pitangueira e a $0,100 \%$ por 2 horas para sementes de uvaieira, mostra-se como uma eficiente ferramenta para a avaliação da viabilidade dessas sementes.
\end{abstract}

Termos para indexação: sementes florestais, sementes recalcitrantes, secagem, teste de viabilidade.

\section{Introduction}

'Grumixameira' (Eugenia brasiliensis Lam.), 'pitangueira' (Eugenia uniflora L.) and 'uvaieira' (Eugenia pyriformis Cambess.) are forest, tree and fruit species with great medicinal, industrial and gastronomic potential, besides being enjoyed for their own consumption in natura and widely used in agroforestry systems (Lamarca et al., 2013). These species belong to the Myrtaceae family in Brazil and occur in tropical and subtropical regions. They have large seeds with wide germination plasticity (Amador and Barbedo, 2011; Lamarca et al., 2011) and intolerant to desiccation (Delgado and Barbedo, 2007).

${ }^{1}$ Submitted on 09/04/2014. Accepted for publication on 09/17/2014.

${ }^{2}$ Instituto de Botânica, Núcleo de Pesquisa em Sementes, Caixa Postal 68041, 04301012 - São Paulo, SP, Brasil.

*Corresponding author $<$ edmirvicente18@gmail.com> 
Seed quality is maximal at the time of physiological maturity. From that moment, they begin to deteriorate until they lose the ability to germinate. The assessment of quality of seeds by means of vigor tests can be understood as an important component for assessing the physiological quality, allowing to identify the actual state of deterioration and vigor, assisting in decision making regarding the use or disposal of seed lots (Marcos-Filho, 2005).

The main challenge for research on seed vigor tests is to identify the decay events that precede the loss of germination, such as those related to the membrane systems and the enzymatic activities. Thus, within this context, is highlighted the tetrazolium test, as already shown for seeds of brazilwood (Caesalpinia echinata) (Lamarca et al., 2009), sunflower (Helianthus annuus) (Silva et al., 2013), jabuticaba (Plinia cauliflora) (Hössel et al., 2013) and pineapple guava (Acca sellowiana) (Sarmento et al., 2013). The tetrazolium test is a rapid test for estimating the vigor and viability of seeds. It is based on the activity of dehydrogenase enzymes that reduce the 2,3,5 triphenyltetrazolium chloride in the living tissues, for where hydrogen ions are transferred. When the seeds are immersed in the solution of tetrazolium, this is propagated by the tissues causing in living cells the reduction reaction, resulting in the formation of a red non-diffusible compound, referred to as triphenilformazan indicating respiratory activity and that the tissue is viable. Non-viable tissues do not react with the solution, remaining in their natural color and damaged tissues exhibit intense red staining (França-Neto, 1994).

For seeds of various cultivated species, the tetrazolium test has already been extensively researched and has defined and applied its methodology. Regarding forest species, studies described in the literature demonstrate the advances in methodological adequacy test for seeds, but it is not possible to standardize the methodology for implementing the same, since each species needs its own processes, as seen by changes in the concentration optimal tetrazolium solution, for example, 0.050 $\%$ for Brazilian firetree or Brazilian fern tree (Schizolobium parahyba) (Ferreira et al., 2007) and brazilwood (Lamarca et al., 2009), 0.075\% for angico-de-bezerro (Piptadenia moniliformis Benth.) (Azerêdo et al., 2011), 0.100\% for pitanga-do-mato (Myrcia crocea) (Masetto et al., 2009) and jabuticabeira (Hössel et al., 2013) and $0.500 \%$ for macaúba (Acrocomia aculeata and A. vinifera) (Ribeiro et al., 2010) and pineapple guava (Sarmento et al., 2013).

However, in the forestry seeds there is little information in the literature about the appropriate methodology for the implementation of the tetrazolium test, especially when dealing with desiccation intolerant seeds, namely, the ones of short-term storage, such as, for example, seeds of $E$. brasiliensis, E. uniflora and E. pyriformis. Thus, the present study aimed to suit the methodology of the tetrazolium test for seeds of grumixameira, pitangueira and uvaieira, to assess the viability of these seeds.

\section{Material and Methods}

Seed collection: the seeds of E. brasiliensis, E. uniflora and E. pyriformis. were obtained from ripe fruit freshly dispersed, in 2007, based on the information of maturation and collection of Delgado and Barbedo (2007). The fruits of grumixameira were from the municipality of São Paulo - SP $\left(23^{\circ} 38^{\prime} \mathrm{S}, 46^{\circ} 37^{\prime} \mathrm{W}, 785 \mathrm{~m}\right)$ and of pitangueira and uvaieira

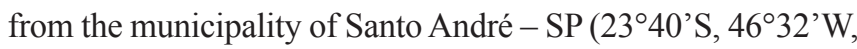
$791 \mathrm{~m}), \mathrm{Cwb}$ regions, according to the climate classification of Köppen-Geiger (Peel et al., 2007). After collection, with the aid of running water and a sieve, the seeds were removed from fruits and stored in a cold chamber at $7{ }^{\circ} \mathrm{C}$ until the beginning of the experiments, not exceeding seven days after collection (Delgado and Barbedo, 2007).

Physical and physiological assessments: later, the seeds were characterized by water content, water potential, germination and electrical conductivity. The water content (WC) was gravimetrically determined by the oven method at $103{ }^{\circ} \mathrm{C}$ for 17 hours, and the results were presented in

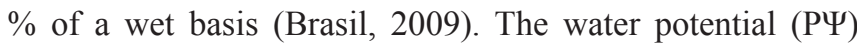
was measured in seeds cut in the middle and analyzed in a potentiometer WP4 (Decagon Devices, Pullman, WA, USA), based on the temperature of the dew point of the air in equilibrium with the sample examined (Daws et al., 2004). The water potential values were checked by means of water sorption isotherms in solutions of polyethylene glycol 6000.

The germination test was conducted in germination chambers at $25{ }^{\circ} \mathrm{C}$ with constant light and $100 \%$ relative humidity, using the roll paper method (filter paper) with two leaves for the basis and one for coverage (Brasil, 2009). Four replications of 15 seeds each were used. Germination assessments were performed every 3 days for 70 days (Delgado and Barbedo, 2007), by registering the seeds that have issued a primary root, for the calculation of germinable seeds (GS) and those that produced normal seedlings, for the calculation of germination $(\mathrm{G})$, both results presented in percentage. The first count (FC), by the germination test, was also recorded.

As a measure of seed vigor, the index of germination speed (IVG) was rated using the counts of the germination test itself, using the formula of Maguire (1962) and the germination average time (GT), according to Borghetti and Ferreira (2004). To determine the day of the first count, for each species was used as reference the germination test of the 
seeds without drying, determining the day when it presented with approximately $50 \%$ of germinable seeds, which occur at the 7 th day of countdown for grumixameira, at the 14th day for pitangueira and the 22nd for uvaieira; a methodology adapted from Brasil (2009).

The electrical conductivity test (EC) was determined by means of digital conductivity meter bench MA150 (Marconi, Piracicaba), measured by means of a standard solution $\left(146.7 \mu \mathrm{S} . \mathrm{cm}^{-1}\right)$. Thus, samples of intact seeds ( 15 per replicate) were placed in disposable plastic cups of $300 \mathrm{~mL}$, containing $75 \mathrm{~mL}$ of deionized water (four cups, each being considered a replication), in a B.O.D. (Biochemical Oxigen Demand) type environmental chamber set to a constant temperature of $20^{\circ} \mathrm{C}$ in the absence of light. The assessments were performed after 24 hours of conditioning (Vieira, 1994). The results obtained, in $\mu \mathrm{S} \mathrm{cm}^{-1}$, were divided by the equivalent dry weight of the sample $(\mathrm{g})$, being presented by unit of dry weight in $\mu{\mathrm{S} . \mathrm{cm}^{-1}} \cdot \mathrm{g}^{-1}$. To obtain the equivalent in dry weight, seed samples were taken for determination of total dry weight in the same test for the determination of water content (Barbedo and Cicero, 1998; Martini Neto et al., 2014).

Concentration of tetrazolium solution and incubation period: different concentrations of salt 2,3,5 triphenyltetrazolium chloride for different periods of incubation were analyzed for seeds. Pretests showed the most appropriate method for the implementation of the tetrazolium test, namely, immersion of intact seeds for 3 hours at $25^{\circ} \mathrm{C}$ in water, to determine the preconditioning, which was made to match the water content of the seeds with and without drying and to soften the tissues and allow the development of a more obvious staining. After preconditioning, the longitudinal splitting of the seeds was performed, immediately immersing the two parts in the tetrazolium solution, so as to maximally avoid exposure of the cut parts to air, since the seeds of the species of the present study after cutting and in contact with air quickly oxidize, which would hinder the assessment. Such longitudinal sectioning was necessary because preliminary tests showed that there is no staining of intact seeds when incubated in tetrazolium (Figures $1 \mathrm{~A}$ and $\mathrm{B}$ ).

Therefore, the seeds of grumixameira, pitangueira and uvaieira (four replications of 15 seeds) were stained in the aqueous solution of tetrazolium in the concentrations of $0.100 \%, 0.125 \%$ and $0.250 \%$ for 2,3 and $6 \mathrm{~h}$, at $35{ }^{\circ} \mathrm{C}$ in the dark. At the end of staining, the seeds were washed in running water and left immersed in water until the beginning of the assessments, in which the surface of the embryo was assessed (Figure 1C). Embryos were assessed individually with the aid of a magnifying glass and tweezers, observing the presence and location of damage on their surface and were separated into categories of viable and non-viable, according to the different staining patterns, ranging from intense red until the milky white or absence of color (Figure 1) (Masetto et al., 2009). The color differentiation of tissues followed the criteria established by França-Neto (1994), namely, pinkish for a healthy tissue, intense red for a tissue in deterioration and color missing for a dead tissue.

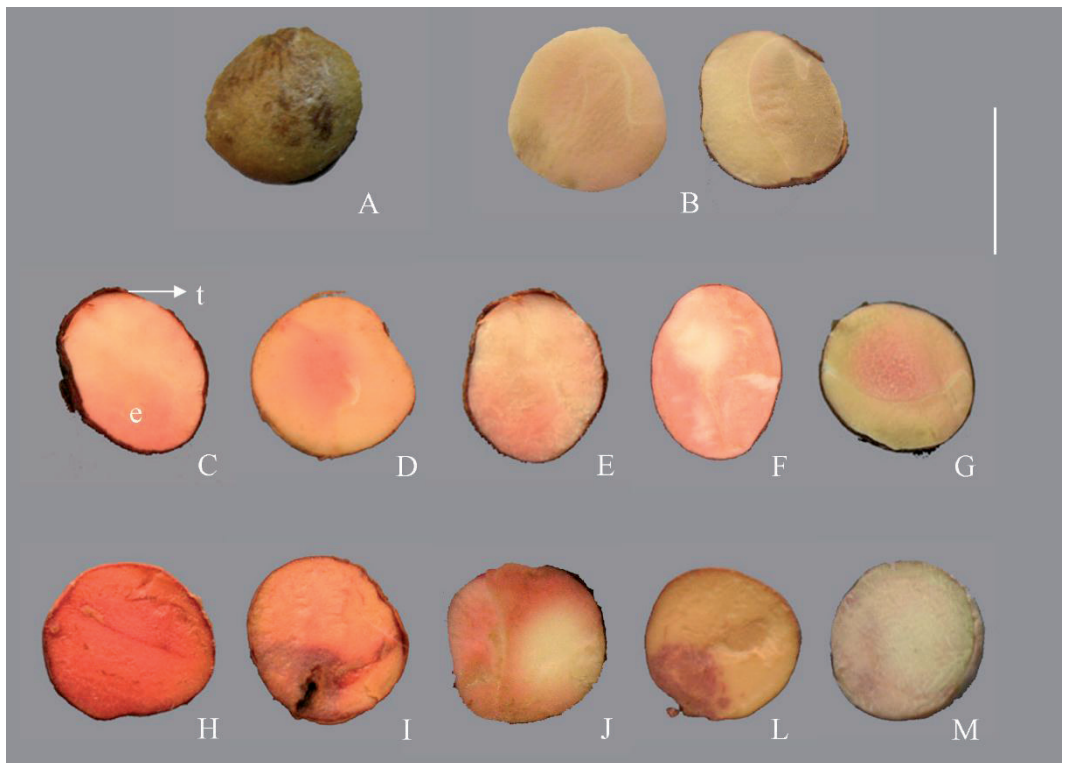

Figure 1. Staining of seeds of E. brasiliensis, E. uniflora and E. pyriformis. by the tetrazolium test. A and B = intact seeds incubated, demonstrating that they do not acquire sufficient staining for analysis. $\mathrm{C}$ to $\mathrm{M}=$ classes for assessment of the viability of seeds. $\mathrm{C}-\mathrm{G}$ (viable seeds), $\mathrm{C}=$ class $\mathrm{I}$ and $\mathrm{D}-\mathrm{G}=$ class $\mathrm{II}$. $\mathrm{H}-\mathrm{M}$ (non viable seeds), $\mathrm{H}=$ class III, $\mathrm{I}-\mathrm{L}=$ class $\mathrm{IV}$ and $\mathrm{M}=$ class V. On image $\mathrm{C}, \mathrm{E}=$ surface of the embryo after the longitudinal section, and $\mathrm{t}=$ coat of the seeds. Scale of $1 \mathrm{~cm}$. 
Attributes of the physiological quality of seeds without or after drying: seeds of grumixameira, pitangueira and uvaieira, after removal of the control sample (without drying), were subjected to three levels of controlled drying in an oven. Drying was carried out intermittently, with 10 hours at $40{ }^{\circ} \mathrm{C}$ followed by 14 hours of standing at $20-25^{\circ} \mathrm{C}$, termed mild drying, intermediate drying and severe drying, trying to bring the seeds to target water content in $45 \%, 40 \%$ and $35 \%$ of a wet basis, namely, when the vigor and germination are affected (Delgado and Barbedo, 2007). To do so, periodically, based on the value of the dry weight of the seeds, samples were taken and assessed for water content, water potential, germination test, electrical conductivity test, as described above, and tetrazolium test.

The tetrazolium test was conducted based on the best staining results at $35{ }^{\circ} \mathrm{C}$ in the dark, obtained from the previous experiment, which were: a concentration of $0.250 \%$ of the tetrazolium solution for 3 hours of incubation for seeds of grumixameira; a concentration of $0.125 \%$ for 3 hours of incubation for seeds of pitangueira; and a concentration of $0.100 \%$ for 2 hours of incubation for seeds of uvaieira. The assessments were performed as previously described.

Classes for assessment of viability: after setting the best combination of concentration of tetrazolium solution, incubation time for staining and assessments of seeds with different drying levels, classes for viability assessment (Figure 1) were defined according to the tissue color of the embryo. For that, each seed was classified as viable (able to issue primary root and/or produce normal seedling) and non viable (without seed ability to issue root, but with living tissues and/or seeds without living tissues).

The classes provided were: classes I and II (viable seeds). Class I - embryos with uniform a rosy hue staining; Class II - areas with intense red or missing color (less than $50 \%$ of the total surface of the embryo) or embryo ends with missing color, but the central area in a rosy color. Classes III, IV and $\mathrm{V}$ (non viable seeds). Class III - embryos with intense red staining in its entirety; Class IV - wide areas in intense red or missing color (over $50 \%$ of the total surface of the embryo), including the most central area; Class V - completely discolored embryos.

Experimental design and statistical analyses: the experimental design was completely randomized in a $3 \times 3$ factorial diagram (solution concentration versus incubation period), with four replicates of 15 seeds. In the results of physiological quality the drying levels for each species were compared (with four replicates of 15 seeds). The data obtained were subjected to analysis of variance (F test) at $5 \%$ significance level. Where relevant, the averages were compared by Tukey test, also at the level of $5 \%$. Subsequently, the simple correlation coefficients between physical and physiological data were calculated for seeds of grumixameira, pitangueira and uvaieira, without or after three drying levels and the significance was determined by the $\mathrm{t}$ test at $5 \%$ probability (Santana and Ranal, 2004).

\section{Results and Discussion}

Concentration of tetrazolium solution and staining period: the analysis of variance showed a significant interaction between factors solution concentration and incubation period for the data of viable seeds obtained by the tetrazolium test (Table 1). It is noticed that the combinations that favored better analysis and visualization of damage to the surface of the embryo (Figure 1), as well as that neared the results of the germination test (Tables 1 and 2), were: $0.250 \%$ of the tetrazolium solution for 3 hours of incubation for seeds of grumixameira, $0.125 \%$ for 3 hours for seeds of pitangueira and $0.100 \%$ for 2 hours for seeds of uvaieira (Table 1), considered the ideal combinations for each species, all at a constant temperature of $35^{\circ} \mathrm{C}$ and in the dark.

Table 1. Viable seeds (\%) of grumixameira, pitangueira and uvaieira, analyzed by the tetrazolium test, due to the variation in staining period and the concentration of salt.

\begin{tabular}{ccccc}
\hline \multirow{2}{*}{ Species } & $\begin{array}{c}\text { Staining } \\
\text { time }\end{array}$ & \multicolumn{3}{c}{ Concentration of the solution } \\
\cline { 3 - 5 } & $0.100 \%$ & $0.125 \%$ & $0.250 \%$ \\
\hline Grumixameira & 2 hours & $50 \mathrm{aB} *$ & $53 \mathrm{aB}$ & $70 \mathrm{bA}$ \\
& 3 hours & $35 \mathrm{bC}$ & $55 \mathrm{aB}$ & $85 \mathrm{aA}$ \\
& 6 hours & $55 \mathrm{aA}$ & $65 \mathrm{aA}$ & $28 \mathrm{cB}$ \\
C.V. (\%) & & & 15.05 & \\
\hline Pitangueira & 2 hours & $33 \mathrm{aB}$ & $68 \mathrm{aA}$ & $58 \mathrm{aA}$ \\
& 3 hours & $45 \mathrm{aB}$ & $83 \mathrm{aA}$ & $15 \mathrm{bC}$ \\
& 6 hours & $40 \mathrm{aA}$ & $10 \mathrm{bB}$ & $0 \mathrm{bB}$ \\
C.V. (\%) & & & 26.65 & \\
\hline Uvaieira & 2 hours & $83 \mathrm{aA}$ & $45 \mathrm{aB}$ & $30 \mathrm{aB}$ \\
& 3 hours & $53 \mathrm{bA}$ & $53 \mathrm{aA}$ & $0 \mathrm{bB}$ \\
& 6 hours & $40 \mathrm{bA}$ & $5 \mathrm{bB}$ & $0 \mathrm{bB}$ \\
C.V. (\%) & & & 27.74 & \\
\hline
\end{tabular}

* Means followed by the same letter (lowercase in columns, uppercase in rows) do not differ by Tukey test at $5 \%$.

As the combinations (concentration and period) were distanced from the ideal, there was a decrease of seeds classified as viable (Table 1), since when the concentration and the period decreased, embryo development with weaker staining color or missing color increased (Figure 1M), and 
when the concentration and the period increased, embryo development with stronger coloration, namely, intense red, increased (Figure 1H). For example, for grumixameira, the combinations of $0.100 \%$ or $0.125 \%$ for 2 hours developed a very light rosy staining or missing color and the combinations of $0.100 \%, 0.125 \%$ or $0.250 \%$ for 6 hours developed an intense red staining, combinations that hampered assessments and classified a smaller amount of viable embryos (Table 1).

Although the species are of the same genus, it is observed that they differ among the ideal combinations for using the tetrazolium test. Study undertaken by Masetto et al. (2009), for "pitanga-domato" (Eugenia pleurantha), namely, a species of the same genus, demonstrated that the optimal combination of the tetrazolium test ( $0.100 \%$ for 4 hours) also differed from this study. The differences were even more pronounced for species of different genera but of the same family (Myrtaceae) from the ones of the present study, as seen by Hössel et al. (2013) for jabuticabeira (1.000\% for 24 hours) and by Sarmento et al. (2013) for pineapple guava $(0.500 \%$ for 4 hours). Other studies also revealed differences between the species, as seen by Lamarca et al. (2009) for seeds of brazilwood
( $0.050 \%$ for 2 hours), by Ribeiro et al. (2010) for seeds of macaúba $(0.500 \%$ for 4 hours) and by Carvalho et al. (2014) for seeds of sorghum $(0.100 \%$ for 3 hours). Such variations emphasize that for the use of the tetrazolium test in seeds there is the need to adapt the methodology for each species.

Attributes of the physiological quality of seeds without or after drying: the results of the physical determinations and the attributes of the seed physiological quality without drying or after three levels of drying are shown in Table 2. It is noticed that the water content decreased as drying increased and water potential became more negative. It is observed that the decrease in water content influenced the seed physiological quality (Table 2), including significant correlations between water content and physiological attributes (Table 3), thus constituting three different drying levels (mild, intermediate and severe) and therefore different levels of physiological characteristics (Table 2). Studies with desiccation intolerant seeds demonstrate the efficiency of the use of controlled drying for obtaining seeds with different physiological quality, such as those conducted by Delgado and Barbedo (2007), Bonjovani and Barbedo (2008), Lamarca et al. (2011) and Ntuli et al. (2014).

Table 2. Water content (WC), water potential (PY), germinable seeds (GS), germination (G), index of germination speed (IVG), mean germination time (GT), first count (FC), electrical conductivity test (EC) and viable seed by the tetrazolium test (VSTZ) of seeds of grumixameira, pitangueira and uvaieira, without drying and after three levels of drying.

\begin{tabular}{|c|c|c|c|c|c|c|c|c|c|}
\hline Level of drying & $\begin{array}{l}\text { WC } \\
(\%)\end{array}$ & $\begin{array}{c}\mathrm{P \Psi} \\
(-\mathrm{MPa})\end{array}$ & $\begin{array}{l}\text { GS } \\
(\%)\end{array}$ & $\begin{array}{l}\text { G } \\
(\%)\end{array}$ & IVG & GT & $\begin{array}{l}\mathrm{FC} \\
(\%)\end{array}$ & $\begin{array}{c}\mathrm{EC} \\
\left(\mu \mathrm{S} . \mathrm{cm}^{-1} \cdot \mathrm{g}^{-1}\right)\end{array}$ & $\begin{array}{l}\text { VSTZ } \\
(\%)\end{array}$ \\
\hline & \multicolumn{9}{|c|}{ Grumixameira } \\
\hline Without drying & $46.16 \mathrm{a}^{*}$ & $1.40 \mathrm{c}$ & $98 \mathrm{a}$ & $94 \mathrm{a}$ & $1.17 \mathrm{a}$ & $12.70 \mathrm{c}$ & $46 \mathrm{a}$ & $8.90 \mathrm{~b}$ & $85 \mathrm{a}$ \\
\hline Mild & $45.47 \mathrm{~b}$ & $4.56 \mathrm{~b}$ & $98 \mathrm{a}$ & $92 \mathrm{a}$ & $1.15 \mathrm{a}$ & $12.62 \mathrm{c}$ & $39 a$ & $18.66 \mathrm{ab}$ & $77 \mathrm{ab}$ \\
\hline Intermediate & $42.44 \mathrm{c}$ & $7.75 \mathrm{a}$ & $92 \mathrm{ab}$ & $88 \mathrm{a}$ & $0.69 \mathrm{~b}$ & $20.48 \mathrm{~b}$ & $17 \mathrm{~b}$ & $20.17 \mathrm{ab}$ & $69 \mathrm{~b}$ \\
\hline Severe & $40.41 \mathrm{~d}$ & $8.04 \mathrm{a}$ & $65 \mathrm{~b}$ & $56 \mathrm{~b}$ & $0.27 \mathrm{c}$ & $30.27 \mathrm{a}$ & $0 \mathrm{~b}$ & $25.49 \mathrm{a}$ & $15 \mathrm{c}$ \\
\hline \multirow[t]{2}{*}{ C.V. (\%) } & 2.72 & 8.86 & 15.19 & 17.23 & 13.19 & 13.68 & 37.64 & 39.58 & 10.78 \\
\hline & \multicolumn{9}{|c|}{ Pitangueira } \\
\hline Without drying & $59.62 \mathrm{a}$ & $0.86 \mathrm{c}$ & $100 \mathrm{a}$ & $100 \mathrm{a}$ & $0.76 \mathrm{~b}$ & $15.60 \mathrm{c}$ & $66 \mathrm{a}$ & $4.56 \mathrm{~b}$ & $83 \mathrm{a}$ \\
\hline Mild & $56.98 \mathrm{a}$ & $1.53 \mathrm{c}$ & $97 \mathrm{a}$ & $90 \mathrm{a}$ & $1.04 \mathrm{a}$ & $17.86 \mathrm{c}$ & $75 \mathrm{a}$ & $7.15 \mathrm{~b}$ & $75 \mathrm{a}$ \\
\hline Intermediate & $48.95 \mathrm{~b}$ & $4.45 \mathrm{~b}$ & $95 \mathrm{a}$ & $92 \mathrm{a}$ & $0.63 \mathrm{c}$ & $26.18 \mathrm{~b}$ & $18 \mathrm{~b}$ & $5.29 \mathrm{~b}$ & $50 \mathrm{~b}$ \\
\hline Severe & $37.45 \mathrm{c}$ & $11.32 \mathrm{a}$ & $58 \mathrm{~b}$ & $37 \mathrm{~b}$ & $0.20 \mathrm{~d}$ & $44.91 \mathrm{a}$ & $0 \mathrm{c}$ & $20.84 \mathrm{a}$ & $30 \mathrm{c}$ \\
\hline \multirow[t]{2}{*}{ C.V. $(\%)$} & 2.89 & 20.98 & 8.99 & 9.73 & 8.43 & 6.01 & 18.99 & 47.31 & 11.28 \\
\hline & \multicolumn{9}{|c|}{ Uvaieira } \\
\hline Without drying & $60.47 \mathrm{a}$ & $0.95 \mathrm{c}$ & $100 \mathrm{a}$ & $98 \mathrm{a}$ & $0.42 \mathrm{~b}$ & $26.35 \mathrm{~b}$ & $50 \mathrm{~b}$ & $4.58 \mathrm{~b}$ & $83 \mathrm{a}$ \\
\hline Mild & $49.42 \mathrm{~b}$ & $6.42 \mathrm{~b}$ & $98 \mathrm{a}$ & $95 \mathrm{a}$ & $0.53 \mathrm{a}$ & $19.40 \mathrm{~b}$ & $85 \mathrm{a}$ & $3.40 \mathrm{~b}$ & $85 \mathrm{a}$ \\
\hline Intermediate & $39.85 \mathrm{c}$ & $10.44 \mathrm{a}$ & $35 \mathrm{~b}$ & $18 \mathrm{~b}$ & $0.09 \mathrm{c}$ & $40.33 \mathrm{a}$ & $3 \mathrm{c}$ & $5.49 \mathrm{~b}$ & $45 \mathrm{~b}$ \\
\hline Severe & $35.28 \mathrm{~d}$ & $11.38 \mathrm{a}$ & $33 \mathrm{~b}$ & $18 \mathrm{~b}$ & $0.08 \mathrm{c}$ & $44.02 \mathrm{a}$ & $0 \mathrm{c}$ & $17.63 \mathrm{a}$ & $18 \mathrm{c}$ \\
\hline C.V. $(\%)$ & 3.41 & 14.50 & 16.59 & 17.02 & 18.86 & 12.71 & 37.32 & 39.72 & 9.39 \\
\hline
\end{tabular}

*Means followed by the same letter do not differ among themselves by the Tukey test at $5 \%$.

As for the physiological attributes, GS, G, IVG, FC and viable seed by the tetrazolium test (VSTZ) decreased with increasing drying and GT and EC increased (Table 2), observing significant differences from the intermediate drying. When comparing the seeds with drying and the ones with intermediate drying, for grumixameira and pitangueira 
it is verified that GS and G did not significantly differ, but VSTZ did, as well as IVG, GT and FC. As for uvaieira, GS and $\mathrm{G}$, as well as IVG, GT, FC and VSTZ differed between the seeds without drying and the ones with intermediate drying (Table 2). When comparing the seeds with intermediate drying and the ones with severe drying, it is verified that for grumixameira there was a difference for G, IVG, GT and VSTZ, for pitangueira there was a difference for GS, G, IVG,
GT, EC and VSTZ and for uvaieira there was a difference for EC and VSTZ (Table 2). Damage by drying, observed by the tetrazolium test, were characteristic in seeds of grumixameira, pitangueira and uvaeira. It was observed that the tissues of the embryos will lose vitality inwardly. Figure $1 \mathrm{G}$ is a representation of damage by drying, in which the end of the embryo presents color missing (dead tissue), but the central region in a rosy color (alive and healthy tissue).

Table 3. Simple correlation coefficients (r) between physical and physiological seed data of grumixameira, pitangueira and uvaieira, without or after three levels of drying.

\begin{tabular}{|c|c|c|c|c|c|c|c|c|}
\hline & $\mathrm{P} \Psi$ & GS & G & IVG & GT & $\mathrm{FC}$ & $\mathrm{EC}$ & VSTZ \\
\hline WC & $-0.92 *$ & $0.78 *$ & $0.79 *$ & 0.55 & $-0.66^{*}$ & $0.82 *$ & $-0.71 *$ & $0.80 *$ \\
\hline $\mathrm{P \Psi}$ & & $-0.85^{*}$ & $-0.86^{*}$ & $-0.75^{*}$ & $0.81 *$ & $-0.75^{*}$ & 0.55 & $-0.79 *$ \\
\hline GS & & & $0.99 *$ & $0.80 *$ & $-0.89^{*}$ & $0.75 *$ & -0.37 & $0.83 *$ \\
\hline $\mathrm{G}$ & & & & $0.78^{*}$ & $0.90 *$ & $0.75^{*}$ & -0.39 & $0.83^{*}$ \\
\hline IVG & & & & & $-0.91 *$ & $0.62 *$ & -0.19 & $0.73^{*}$ \\
\hline GT & & & & & & $-0.74 *$ & 0.30 & $-0.83 *$ \\
\hline $\mathrm{FC}$ & & & & & & & $-0.64 *$ & $0.85^{*}$ \\
\hline $\mathrm{EC}$ & & & & & & & & $-0.62 *$ \\
\hline
\end{tabular}

$\mathrm{WC}=$ water content, $\mathrm{P \Psi}=$ water potential, $\mathrm{GS}=$ germinable seeds, $\mathrm{G}=$ germination, $\mathrm{IVG}=$ index of germination speed, $\mathrm{GT}=$ mean germination time, $\mathrm{FC}$ $=$ first count, $\mathrm{EC}=$ electrical conductivity test and $\mathrm{VSTZ}=$ viable seed by the tetrazolium test. $(*)=\mathrm{r}$ significant at $5 \%$ of probability, without asterisk $=$ non significant correlations.

The amount of physiological attributes that differ between the drying levels for each species must be associated with desiccation tolerance, since studies have reported differences in the degree of desiccation tolerance among seeds of grumixameira, pitangueira and uvaieira (Delgado and Barbedo, 2007). It is verified that the tetrazolium test proves to be consistent to analyze changes in the physiological quality of seeds of these three species. When changes in physiological quality were not identified by the final values of GS and G, but by IVG, GT and FC, the tetrazolium test (VSTZ) had also identified (Table 2). It is also observed that VSTZ showed a significant correlation with all the variables obtained by the germination test (GS, G, IVG, GT and FC) and also with the electrical conductivity test (EC), something that had occurred for the germination test only with the variable FC (Table 3).

The loss of seed physiological quality occurs gradually due to the deterioration process and may be of biochemical, physical, physiological or genetic origins, presented as early events in damage to the membrane systems, followed by a decrease of vigor until loss of ability to germinate (MarcosFilho, 2005). Therefore, in the present study, the tetrazolium test could identify early events of loss of seed physiological quality, something which was not possible for the end result of the germination test. Also due to the positive correlation between the tetrazolium test and conductivity test (Table 3 ), this one used to measure the permeability damage to membrane systems (Barbedo and Cícero, 1998).

Several studies show the efficiency of the tetrazolium test to diagnose the state of physiological quality of seeds, as observed by Lamarca et al. (2009) for seeds of brazilwood, subjected to accelerated aging, by Rego et al. (2013) for seeds of guaçatonga (Casearia sylvestris Sw.) and "murta" (Myrtus L.), subjected to controlled drying, by Azerêdo et al. (2011) for seeds of "angico-de-bezerro", by Hössel et al. (2013) for seeds of jabuticabeira and by Sarmento et al. (2013) for seeds of pineapple guava, subjected to different storage conditions and times.

Finally, the results of this study showed that, since the tetrazolium solution concentration and staining the time are correctly ajusted, it is possible to establish the categories of seed viability for grumixameria, pitangueira and uveira. Thus, tetrazolium test shows up as an important tool for a quick and efficient diagnosis of the real state of physiological quality of these seeds, with or without controlled drying.

\section{Conclusions}

The tetrazolium test conducted on the solution concentration for the period of staining, at $0.250 \%$ for 3 hours for seeds of E. brasiliensis, at $0.125 \%$ for 3 hours for the 
seeds of E. uniflora and at $0.100 \%$ for 2 hours for the seeds of E. pytiformis at constant room temperature of $35^{\circ} \mathrm{C}$, proves efficient for assessing the physiological quality of these seeds.

\section{Acknowledgments}

The authors thank the Municipality of Santo André and the Institute of Botany for authorizing the collection of plant material; also CAPES (Coordenação de Aperfeiçoamento de Pessoal de Nível Superior) for the postgraduate scholarship awarded to E.V. Lamarca and CNPq (Conselho Nacional de Desenvolvimento Científico e Tecnológico - National Counsel of Technological and Scientific Development) the fellowship awarded to C.J. Barbedo.

\section{References}

AMADOR, T.S.; BARBEDO, C.J. Potencial de inibição da regeneração de raízes e plântulas em sementes germinantes de Eugenia pyriformis. Pesquisa Agropecuária Brasileira, v.46, n.8, p.814-821, 2011. http://www.scielo.br/ pdf/pab/v46n8/05.pdf

AZERÊDO, G.A.; PAULA, R.C.; VALERI, S.V. Viabilidade de sementes de Piptadenia moniliformis Benth. pelo teste de tetrazólio. Revista Brasileira de Sementes, v.33, n.1 p.061-068, 2011. http://www.scielo.br/pdf/rbs/v33n1/07.pdf

BARBEDO, C.J.; CICERO, S.M. Utilização do teste de condutividade elétrica para previsão do potencial germinativo de sementes de ingá. Scientia Agricola, v.55, n.2, p.249-259, 1998. http://www.scielo.br/scielo. php?script=sci_arttext\&pid=S0103-90161998000200013

BONJOVANI, M.R.; BARBEDO, C.J. Sementes recalcitrantes: intolerantes a baixas temperaturas? embriões recalcitrantes de Inga vera Willd. subsp. affinis (DC.) T. D. Penn. toleram temperatura sub-zero. Revista Brasileira de Botânica, v.31, n.2, p.345-356, 2008. http://www.scielo.br/pdf/rbb/v31n2/ v31n2a17.pdf

BORGHETTI, F.; FERREIRA, A.G. Interpretação de resultados de germinação. In: FERREIRA, A.G.; BORGHETTI, F. (Eds.). Germinação: do básico ao aplicado. Porto Alegre: Artmed, 2004. p.209-222.

BRASIL. Ministério da Agricultura, Pecuária e Abastecimento. Regras para análise de sementes. Ministério da Agricultura, Pecuária e Abastecimento. Secretaria de Defesa Agropecuária. Brasília: MAPA/ACS, 2009. 395 p. http:// www.agricultura.gov.br/arq editor/file/2946 regras analise sementes.pdf.

CARVALHO, T.C.; GRZYBOWSKI, C.R.S.; OHLSON, O.C.; PANOBIANCO, M. Adaptation of the tetrazolium test method for estimating the viability of sorghum seeds. Journal of Seed Science, v.36, n.1, p.246-252, 2014.http://www.scielo.br/pdf/jss/v36n2/v36n2a14.pdf

DAWS, M.I.; LYDALL, E.; CHMIELARZ, P.; LEPRINCE, O.; MATTHEWS, S.; THANOS, C.A.; PRITCHARD, H.W. Developmental heat sum influences recalcitrant seed traits in Aesculus hippocastanum across Europe. New Phytologist, v.162, n.1, p.157-166, 2004. http://onlinelibrary. wiley.com/doi/10.1111/j.1469-8137.2004.01012.x/pdf

DELGADO, L.F.; BARBEDO, C.J. Tolerância à dessecação de sementes de espécies de Eugenia. Pesquisa Agropecuária Brasileira, v.42, n.2, p.265-272, 2007. http://www.scielo.br/pdf/pab/v42n2/16.pdf
FERREIRA, R.A.; OLIVEIRA, L.M.; TONETTI, O.A.O.; DAVIDE, A.C. Comparação da viabilidade de sementes de Schizolobiumparahyba(Vell.) Blake - Leguminosae Caesalpinioideae, pelos testes de germinação e tetrazólio. Revista Brasileira de Sementes, v.29, n.3, p.73-79, 2007. http:// www.scielo.br/pdf/rbs/v29n3/a11v29n3.pdf

FRANÇA-NETO, J.B. O teste de tetrazólio em sementes de soja. In: VIEIRA, R.D.; CARVALHO, N.M. (Ed.). Testes de vigor em sementes. Jaboticabal: FUNEP, 1994. p.87-102.

HÖSSEL, C.; OLIVEIRA, J.S.M.A.; FABIANE, K.C.; WAGNER JÚNIOR, A.; CITADIN, I. Conservação e teste de tetrazólio em sementes de jabuticabeira. Revista Brasileira de Fruticultura, v.35, n.1, p.255-261, 2013. http://www.scielo.br/pdf/rbf/v35n1/29.pdf

LAMARCA, E.V.; LEDUC, S.N.M.; BARBEDO, C.J. Viabilidade e vigor de sementes de Caesalpinia echinata Lam. (pau-brasil - Leguminosae) pelo teste de tetrazólio. Revista Brasileira de Botânica, v.32, n.4, p. 793-803, 2009. http://www.scielo.br/pdf/rbb/v32n4/a17v32n4.pdf

LAMARCA, E.V.; SILVA, C.V.; BARBEDO, C.J. Limites térmicos para a germinação em função da origem de sementes de espécies de Eugenia (Myrtaceae) nativas do Brasil. Acta Botanica Brasilica, v.25, n.2, p. 293-300, 2011. http://www.scielo.br/pdf/abb/v25n2/a05v25n2.pdf

LAMARCA, E.V.; BAPTISTA, W.; RODRIGUES, D.S.; OLIVEIRA JÚNIOR, C.J.F. Contribuições do conhecimento local sobre o uso de Eugenia spp. em sistemas de policultivos e agroflorestas. Revista Brasileira de Agroecologia, v.8, n.3, p.119-130, 2013. http://www.aba-agroecologia.org. br/revistas/index.php/rbagroecologia/article/view/13256/9905.

MAGUIRE, J. D. Speed of germination-aid in selection and evaluation for seedling emergence and vigor. Crop Science, v.2, n.2, p. 176-177, 1962.

MARCOS-FILHO, J. Fisiologia de sementes de plantas cultivadas. Piracicaba: FEALQ. 2005. 495p.

MARTINI NETO, N.; LAMARCA, E.V.; BARBEDO, C.J. Kinetics of solute leachate from imbibing Caesalpinia echinata Lam. (Brazilwood) seeds. Revista Ceres, v.61, n.1, p.90-97, 2014. http://www.scielo.br/pdf/rceres/ v61n1/v61n1a12.pdf

MASETTO, T.E.; DAVIDE, A.C.; FARIA, J.M.R.; SILVA, E.A.A.; REZENDE, R.K.S. Avaliação da qualidade de sementes de Eugenia pleurantha (MYRTACEAE) pelos testes de germinação e tetrazólio. Agrarian, v.2, n.5, p.33-46, 2009. http://www.periodicos.ufgd.edu.br/index. php/agrarian/article/view/802/482

NTULI, T.M.; BERJAK, P.; PAMMENTER, N.W. Tissue diversity in respiratory metabolism and free radical processes in embryonic axes on the white mangrove (Avicennia marina $\mathrm{L}$.) during drying and wet storage. African Journal of Biotechnology, v.13, n.17, p.1813-1823, 2014. http://www. academicjournals.org/article/article1398764350_Ntuli\%20et\%20al.pdf

PEEL, M.C.; FINLAYSON, B.L.; MCMAHON, T.A. Updated world map of the Köppen-Geiger climate classification. Hydrology and Earth System Sciences, v.11, p.1633-1644, 2007. http://www.hydrol-earth-syst-sci. net/11/1633/2007/hess-11-1633-2007.pdf

REGO, S.S.; NOGUEIRA, A.C.; MEDEIROS, A.C.S.; PETKOWICZ, C.L.O.; SANTOS, A.F. Physiological behaviour of Blepharocalyx salicifolius and Casearia decandra seeds on the tolerance to dehydration. Journal of Seed Science, v.35, n.3, p.323-330, 2013.http://www.scielo.br/pdf/jss/v35n3/08.pdf 
RIBEIRO, L.M.; GARCIA, Q.S.; OLIVEIRA, D.M.T.; NEVES, S.C. Critérios para o teste de tetrazólio na estimativa do potencial germinativo em macaúba. Pesquisa Agropecuária Brasileira, v.45, n.4, p.361-368, 2010. http://www.scielo.br/pdf/pab/v45n4/a03v45n4

SANTANA, D.G.; RANAL, M.A. Análise da germinação: um enfoque estatístico. Universidade de Brasília: Brasília, 2004. 248p.

SARMENTO, M.B.; SILVA, A.C.S.; VILLELA, F.A.; SANTOS, K.L.; MATTOS, L.C.P. Teste de tetrazólio para avaliação da qualidade fisiológica em sementes de goiabeira-serrana (Acca sellowiana O. Berg Burret). Revista Brasileira de Fruticultura, v.35, n.1, p.270-276, 2013. http://www.scielo.br/ pdf/rbf/v35n1/31.pdf
SILVA, R.C.; GRZYBOWSKI, C.R.S.; FRANÇA-NETO, J.B.; PANOBIANCO, M. Adaptação do teste de tetrazólio para avaliação da viabilidade e vigor em sementes de girassol. Pesquisa Agropecuária Brasileira, v.48, n.1, p.105-113, 2013. http://www.scielo.br/pdf/pab/v48n1/14.pdf

VIEIRA, R.D. Teste de condutividade elétrica. In: VIEIRA, R.D.; CARVALHO, N.M. (Eds.). Testes de vigor emsementes. Jaboticabal: FUNEP, 1994. p.103-125. 